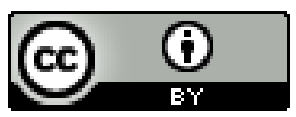

\title{
A CAPOEIRA COMO REFERENCIAL METODOLÓGICO PARA ENFRENTAMENTO DO RACISMO
}

Yuri Miguel Macedo ${ }^{1}$

Eduardo David de Oliveira ${ }^{2}$

\author{
Cinézio Feliciano Peçanha (Mestre Cobra Mansa) ${ }^{3}$
}

Resumo: O presente texto apresenta um relato de experiência de uma oficina de Capoeira Angola realizada no dia 15 de março de 2019 durante o Encontro Corpo, Poética e Ancestralidade na Universidade Federal do Sul da Bahia no Campus Sosígenes Costa em Porto Seguro - BA, a partir da análise da importância do resgate da capoeira e esse papel importante em uma luta contra o racismo, até mesmo dentro das práticas escolares, usamos como aportes teóricos, GOMES (2017, 2018), PASSOS (2019) e MACEDO \& FRANCISCHETTO (2019) o que nos leva a reflexão da prática de metodologias antirracistas e principalmente ancestral, oral e afroreferenciadas.

Palavras-Chaves: Capoeira, Racismo, metodologia.

\section{CAPOEIRA AS A METHODOLOGICAL REFERENCE FOR FACING RACISM}

Abstract: This paper presents an experience report of a Capoeira Angola workshop held on March 15, 2019 during the Body, Poetics and Ancestry Meeting at the Federal University of Southern Bahia at the Sosígenes Costa Campus in Porto Seguro - BA, Brazil. From the analysis of the importance of capoeira rescue and this important role in a fight against racism, even within school practices, we use as theoretical contributions GOMES $(2017,2018)$, PASSOS (2019) and MACEDO \& FRANCISCHETTO (2019). This leads us to reflect on the practice of anti-racist methodologies and especially ancestral, oral and Afro-referenced.

Keywords: Capoeira, Racism, methodology.

\section{CAPOEIRA COMO REFERENCIA METODOLÓGICA PARA ENFRENTAR EL RACISMO}

\footnotetext{
1 Mestrando no Programa de Pós-Graduação em Ensino e Relações Étnico-Raciais da Universidade Federal do Sul da Bahia (UFSB) e Pesquisador do Núcleo de Estudos Afro-Brasileiros da Universidade Federal do Espirito Santo (UFES).

${ }^{2}$ Professor Adjunto da Faculdade de Educação, Universidade Federal da Bahia (UFBA).

3 Doutorando do Programa de Doutorado Multi-Institucional e Multidisciplinar em Difusão do Conhecimento na Universidade Federal da Bahia (UFBA).
} 
Resumen: Este documento presenta un informe de experiencia de un taller de Capoeira Angola celebrado el 15 de marzo de 2019 durante la Reunión del Cuerpo, Poética y Ascendencia en la Universidad Federal del Sur de Bahía en el Campus Sosígenes Costa en Porto Seguro - BA, Brasil. A partir del análisis de la importancia del rescate de capoeira y este importante papel en la lucha contra el racismo, incluso dentro de las prácticas escolares, utilizamos como contribuciones teóricas GOMES (2017, 2018), PASSOS (2019) y MACEDO \& FRANCISCHETTO (2019). lo que nos lleva a reflexionar sobre la práctica de metodologías antirracistas y especialmente ancestrales, orales y afro referenciadas.

Palabras clave: Capoeira, racismo, metodología.

\section{CAPOEIRA, RÉFÉRENCE MÉTHODOLOGIQUE POUR FAIRE FACE AU RACISME}

Résumé: Cet article présente le rapport d'expérience d'un atelier organisé par Capoeira Angola le 15 mars 2019 lors de la réunion sur le corps, la poétique et l'ascendance à l'Université fédérale du sud de la Bahia, sur le campus Sosígenes Costa de Porto Seguro - BA, Brésil. De l'analyse de l'importance du sauvetage de capoeira et de ce rôle important dans la lutte contre le racisme, même dans les pratiques scolaires, nous utilisons comme contributions théoriques GOMES $(2017,2018)$, PASSOS (2019) et MACEDO \& FRANCISCHETTO (2019). ce qui nous amène à réfléchir à la pratique des méthodologies antiracistes et notamment ancestrale, orale et afro-référencée.

Mots-clés: capoeira, racisme, méthodologie.

\section{IBERE}

Ao tecer esse relato de experiência, saudamos inicialmente a nossa ancestralidade que nos permitiu estar aqui e compartilhar esse momento de profunda aprendizagem e troca de saberes através da oralidade, trazer esse subtítulo como "ibere" que em sua tradução do iorubá significa início, queremos aqui caracterizar todas as participações e momentos que ocorreram durante a oficina.

Salientamos que a oficina ocorreu no dia 15 de março de 2019, na Universidade Federal do Sul da Bahia no campus Sosígenes Costa na Cidade de Porto Seguro no território identitário da Costa do "Descobrimento"4 que outrora insistimos em chamar da Costa da Invasão, no extremo sul da Bahia.

Em formato de exposição de ideias e dialogando, o Mestre Cobra Mansa explica aos participantes sobre a importância do resgate ancestral da cultura africana e afrobrasileira que existe em todo território brasileiro.

\footnotetext{
${ }^{4}$ Em abril de 1500, depois de 45 dias de viagem, a esquadra de Pedro Álvares Cabral chegou ao Brasil o fato ficou conhecido como o descobrimento do país. Entretanto, as terras brasileiras já eram ocupadas pelos povos indígenas, ou seja, a chegada dos portugueses, na verdade, foi uma invasão ao país.
} 
Ao abrir esse momento importante para reflexão foi necessário empardecer o momento crucial político que vive no país, o racismo institucional que se vive, a intolerância religiosa e principalmente a marginalização dos negros, pobres e periféricos.

A identidade nessa oficina foi novamente reforçada ao trazer que a capoeira foi um dos instrumentos mais diaspóricos que vive até hoje...”[...] na reconstrução da capoeira angola, são os elementos que traduzem um passado tradicional, ancestral, prémoderno que norteiam os discursos e os fazeres. (Zonzon, 2011) $)^{5}$

\section{$A B I$}

Quando trazemos a palavra “abi” que em sua tradução da palavra em iorubá significa nascer, estamos aqui pontuando sobre a oficina de capoeira que ocorreu no dia 15 de março de 2019 pela manhã, de uma forma que cada roda é uma roda, é um novo nascer, composto de seres e ancestrais diferentes, energias diferentes e principalmente formadas por um conjunto de singularidade e particularidades em cada sujeito.

A construção da sociedade moderna foi caracterizada por produções de binômios, tais como: riqueza e pobreza, homem e mulher e branco e negro. Chegamos ao século XXI e, como resultado desta sociedade, marcadamente ocidental e com traços históricos de colonialismos, podemos encontrar a humanidade com condutas que levam a extremos diferentes como se fossem uma ruptura. Se por um lado pareça assustador, por outro não se pode negar os progressos alcançados, consequentes da lógica capitalista.

Dito isso, acreditamos ser a educação, a área de conhecimento fundamental para fissurar tais estruturas. A Educação é um direito social fundamentado e apresentado pela Constituição da República Federativa do Brasil de 1988 - CF/1988, e está disposto no artigo $6^{\circ}$ dentre os demais direitos sociais.

Podemos ver que na $\mathrm{CF} / 1988$, os direitos estão explicitados no artigo $5^{\circ}$ e $6^{\circ}$ na forma da presente lei, que assim nos profere:

\footnotetext{
5 ZONZON, CN. Capoeira Angola: africana, baiana, internacional. In: MOURA, M. A larga barra da baía: essa província no contexto do mundo [online]. Salvador: EDUFBA, 2011, pp. 130-165. ISBN 97885-232-1209-4.
} 
Art. $5^{\circ}$ Todos são iguais perante a lei, sem distinção de qualquer natureza, garantindo-se aos brasileiros e aos estrangeiros residentes no País a inviolabilidade do direito à vida, à liberdade, à igualdade, à segurança e à propriedade [...] (Brasil, 1988)

Art. $6^{\circ}$ São direitos sociais a educação, a saúde, a alimentação, o trabalho, a moradia, o transporte, o lazer, a segurança, a previdência social, a proteção à maternidade e à infância, a assistência aos desamparados, na forma desta Constituição. (Brasil, 1988)

Empardecendo os artigos supracitados, quero aqui novamente retomar o presente com a seguinte releitura, "todos são iguais perante a lei, sem distinção de qualquer natureza" (Brasil, 1988), também conhecido como o princípio da isonomia ou princípio da igualdade, ou seja, que todas as pessoas são iguais, independente de classe social, etnia, gênero, nacionalidade ou posicionamento político. Mas aqui quero tecer e deixar focado principalmente nas questões étnico-raciais que assola principalmente os espaços públicos e em que o Estado deveria intervir para o combate do racismo e da discriminação que deveria ser um elo com o primeiro direito social apresentado que é a Educação, que é direito de todos e obrigação do Estado e da família.

Concomitante com esses dois artigos supracitados, traz-se a importância dos artigos 215 e 2016 da $\mathrm{CF} / 1988$ :

Art. 215. O Estado garantirá a todos o pleno exercício dos direitos culturais e acesso às fontes da cultura nacional, e apoiará e incentivará a valorização e a difusão das manifestações culturais.

$\S 1^{\circ} \mathrm{O}$ Estado protegerá as manifestações das culturas populares, indígenas e afro-brasileiras, e das de outros grupos participantes do processo civilizatório nacional.

$2^{\circ}$ A lei disporá sobre a fixação de datas comemorativas de alta significação para os diferentes segmentos étnicos nacionais.

$3^{\circ}$ A lei estabelecerá o Plano Nacional de Cultura, de duração plurianual, visando ao desenvolvimento cultural do País e à integração das ações do poder público que conduzem à: (Incluído pela Emenda Constitucional no 48 , de 2005)

I - defesa e valorização do patrimônio cultural brasileiro; (Incluído pela Emenda Constitucional $\mathrm{n}^{\circ} 48$, de 2005)

II - produção, promoção E difusão de bens culturais; (Incluído pela Emenda Constitucional $\mathrm{n}^{\circ} 48$, de 2005)

III - formação de pessoal qualificado para a gestão da cultura em suas múltiplas dimensões; (Incluído pela Emenda Constitucional nº 48, de 2005)

$[\ldots]$

V - valorização da diversidade étnica e regional. (Incluído pela Emenda Constitucional $\mathrm{n}^{\circ} 48$, de 2005)

Art. 216. Constituem patrimônio cultural brasileiro os bens de natureza material e imaterial, tomados individualmente ou em conjunto, portadores de referência à identidade, à ação, à memória dos diferentes grupos formadores da sociedade brasileira, nos quais se incluem: 
I - as formas de expressão;

II - os modos de criar, fazer e viver;

[...]

$\S 1^{\circ}$ O Poder Público, com a colaboração da comunidade, promoverá e protegerá o patrimônio cultural brasileiro, por meio de inventários, registros, vigilância, tombamento e desapropriação, e de outras formas de acautelamento e preservação.

$[\ldots]$

$\S 3^{\circ}$ A lei estabelecerá incentivos para a produção e o conhecimento de bens e valores culturais.

$\S 4^{\circ}$ Os danos e ameaças ao patrimônio cultural serão punidos, na forma da lei.

$\S 5^{\circ}$ Ficam tombados todos os documentos e os sítios detentores de reminiscências históricas dos antigos quilombos. [...] (Brasil, 1988)

A partir dos presentes artigos acima, podemos ver que a CF/1988, também resguarda o exercício dos direitos culturais, direito esse que é cerceado nas escolas e nos espaços públicos quando não deixamos que a cultura que constituiu o Brasil não possa ser falada, divulgada, discutida e principalmente estudada devido aos empasses e influência das Igrejas Cristãs no Brasil que por via contraria o princípio da laicidade que está explícito no inciso VI do artigo $5^{\circ}$ da CF/1988 que assim diz: "é inviolável à liberdade de consciência e de crença, sendo assegurado o livre exercício dos cultos religiosos e garantida, na forma da lei, a proteção aos locais de culto e a suas liturgias". Mas quero retomar a pauta da aplicabilidade da Lei, afim de apontar que na CF/1988 assegura o direito do estudo e manifestações das culturas Afro-Brasileiras. Pontua-se que o Brasil é o país mais negro fora do continente africano a partir do processo de escravidão, outrora que deve ser lembrado e redistribuído todo esse tipo de informação que venho trazer para o estudo da Lei n ${ }^{\circ} 10.639 / 2003$ e sua aplicabilidade na Costa do "Descobrimento".

Além dos artigos descritos da nossa Carta Magna, a Educação brasileira é regida pela Lei Federal $n^{\circ}$ 9.394/1996, que estabelece e as diretrizes e bases da educação nacional que foi alterada em 2003 no que diz respeito à inclusão de uma produção de conhecimento que enaltece os valores civilizatórios das populações africanas e afrobrasileiras com objetivo de promover uma real igualdade de oportunidade de conhecimento sobre todas as nossas matrizes civilizatórias. Assim, em 09 de janeiro de 2003, é sancionada a Lei Federal $n^{\circ} 10.639 / 2003$, que visa e estabelece as diretrizes e

\footnotetext{
${ }^{6}$ Cf. nota 4 .
} 
bases da educação nacional, para incluir no currículo oficial da Rede de Ensino a obrigatoriedade da temática "História e Cultura Afro-Brasileira".

"Art. 26-A. Nos estabelecimentos de ensino fundamental e de ensino médio, públicos e privados, torna-se obrigatório o estudo da história e cultura afrobrasileira e indígena."

$[\ldots]$

"Art. 79-B. O calendário escolar incluirá o dia 20 de novembro como 'Dia Nacional da Consciência Negra"”.

No espaço escolar essa lei deve estar comboiada de políticas que gerem a discussão sobre os temas raciais, na escola, no bairro, no município, no país e no mundo. Devemos atentar para o fato de a lei vir para tentar estancar a sangria do racismo e esse não está presente apenas no espaço escolar, mas é vinculado em toda a sociedade.

Se faz indispensável conhecer as Diretrizes Curriculares para a Educação das Relações Étnico-raciais e o Ensino de História e Cultura Afro-brasileira e Africana.

Assim, a luz das Diretrizes Curriculares para a Educação das Relações Étnicoraciais e para o Ensino de História e Cultura Afro-brasileira e Africana, que trata dos conteúdos tradicionais das várias disciplinas, em especial o Art. $26^{\mathrm{a}}$ da Lei de Diretrizes e Bases da Educação nacional, (Lei 10.639/2003) - garantindo o que está preconizado desde a Constituição Federal em seu art. 3, IV, (...) “o preconceito de origem de raça, sexo, cor, idade e quaisquer outras formas de discriminação" e reconhecem que todos são portadores de singularidade irredutível e que a formação escolar tem de estar atenta para o desenvolvimento de suas personalidades (Art. 208. IV). (Arruda, 2007, p.9)

Vemos que a não integração da população negra em múltiplos campos da sociedade ainda é invisível. Visto que, os negros compõem mais da metade da população brasileira, mas são minoria nos campos político, econômico, midiático, artístico, esportivo, educacional etc.

A Lei $n^{o} 10.639 / 2003$, desde sua promulgação não têm sido efetivamente aplicadas em nenhum âmbito, uma vez que a lei supracitada não está sendo cumprida, o acinte dos órgãos fiscalizadores e formadores, que mascaram um racismo institucionalizado ou uma premissa para não cumprimento da Lei. 


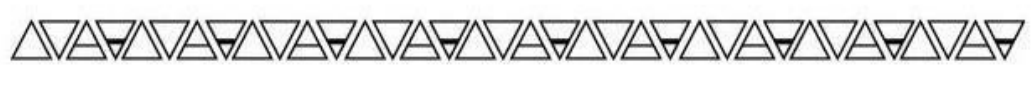

A judicialização nestes casos torna-se um processo de vício do poder público cabendo a ele querer ou não, executar ou não as políticas e saberes referentes a História e Cultura Afro-Brasileira.

E temos a plena certeza que a capoeira é um instrumento muito importante referencial metodológico para enfrentamento do racismo e quebra dos paradigmas existentes sobre o jogo.

\section{$\mathrm{IJO}^{7}$}

O momento de vivência e escrevivência dentro dessa oficina podemos compor com mais ou menos 40 participantes além do oficineiro Mestre Cobra Mansa, onde tinha os seguintes instrumentos musicais: 9 berimbais, 4 pandeiros, 1 atabaque e 1 agogô.

Fora dividido o presente momento em 6 partes, onde inicialmente eram em grandes grupos e posteriormente em duplas. Iniciando a oficina, o Mestre Cobra Mansa expôs a necessidade de uma vivência ancestral onde poderia ser lembrada como a arte da capoeira foi uma arte de resistência dos ex-escravizados ${ }^{8}$, bem como um ritmo de louvação aos ancestrais que ali eram cultuados em seus jogos de lutas e danças.

Seguindo os momentos teve um momento onde os participantes tiveram que fazer a "ginga" em dupla, jogos de pernas, meia lua de frente mais meia lua de costas, jogadas defensivas, movimentos isolados tudo afim de demonstrar que tal da capoeira que mesmo trazida a mais de três séculos para o Brasil, perdura até os dias de hoje.

\footnotetext{
7 Palavra iorubana que significa dança.

8 "Utilizaremos a palavra ex-escravizado, ao invés de escravo, mais uma vez por acreditar na força política das palavras" (Passos,2019)
} 


\section{Imagem 1:}

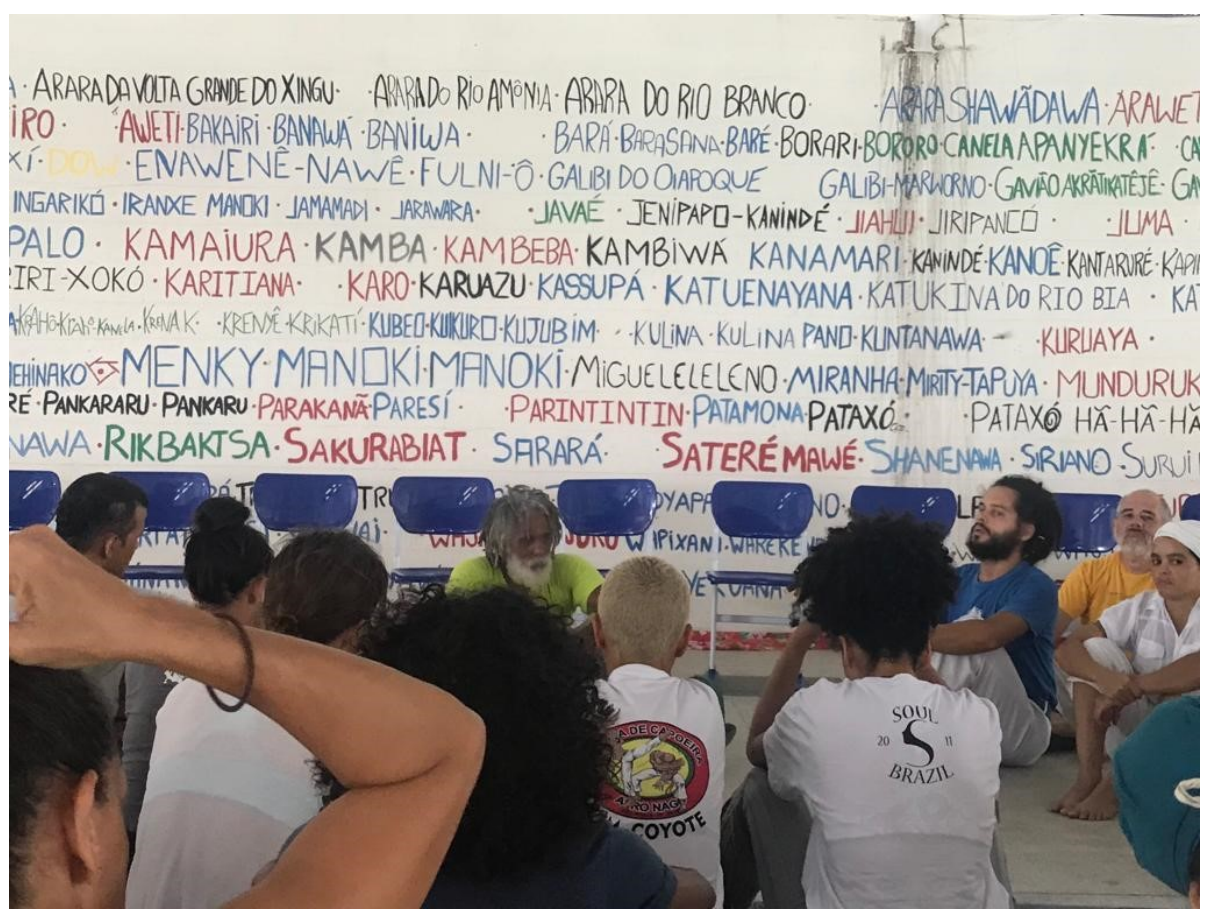

Fonte: Yuri Miguel Macedo (2019)

Após, o ensinamento de vários jogos de corpo, o Mestre Cobra Mansa inicia uma Roda de Capoeira, conde a maioria de seus participantes jogam ou participam cantando em círculo.

\section{Imagem 2:}

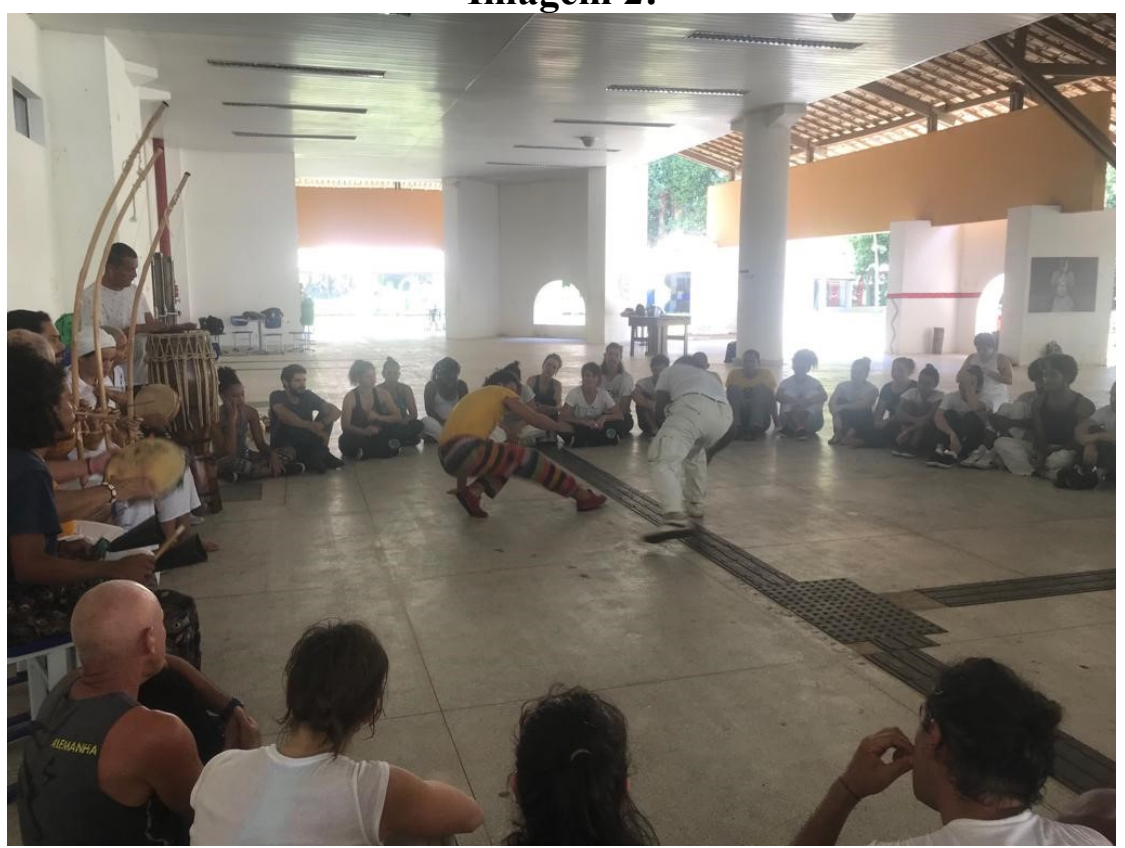

Fonte: Yuri Miguel Macedo (2019) 


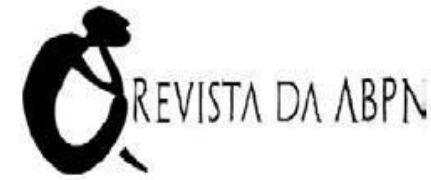

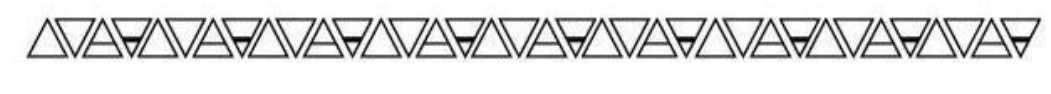

Seguidamente, foi feito um momento de vivência e diálogo com os participantes da oficina para falar como seria esse jogo dentro das escolas, quais seriam os principais fatores que contribuiriam para que esse método, a capoeira, ajudasse na promoção da igualdade racial, e fortalecimento da Educação para as Relações Étnico-Raciais.

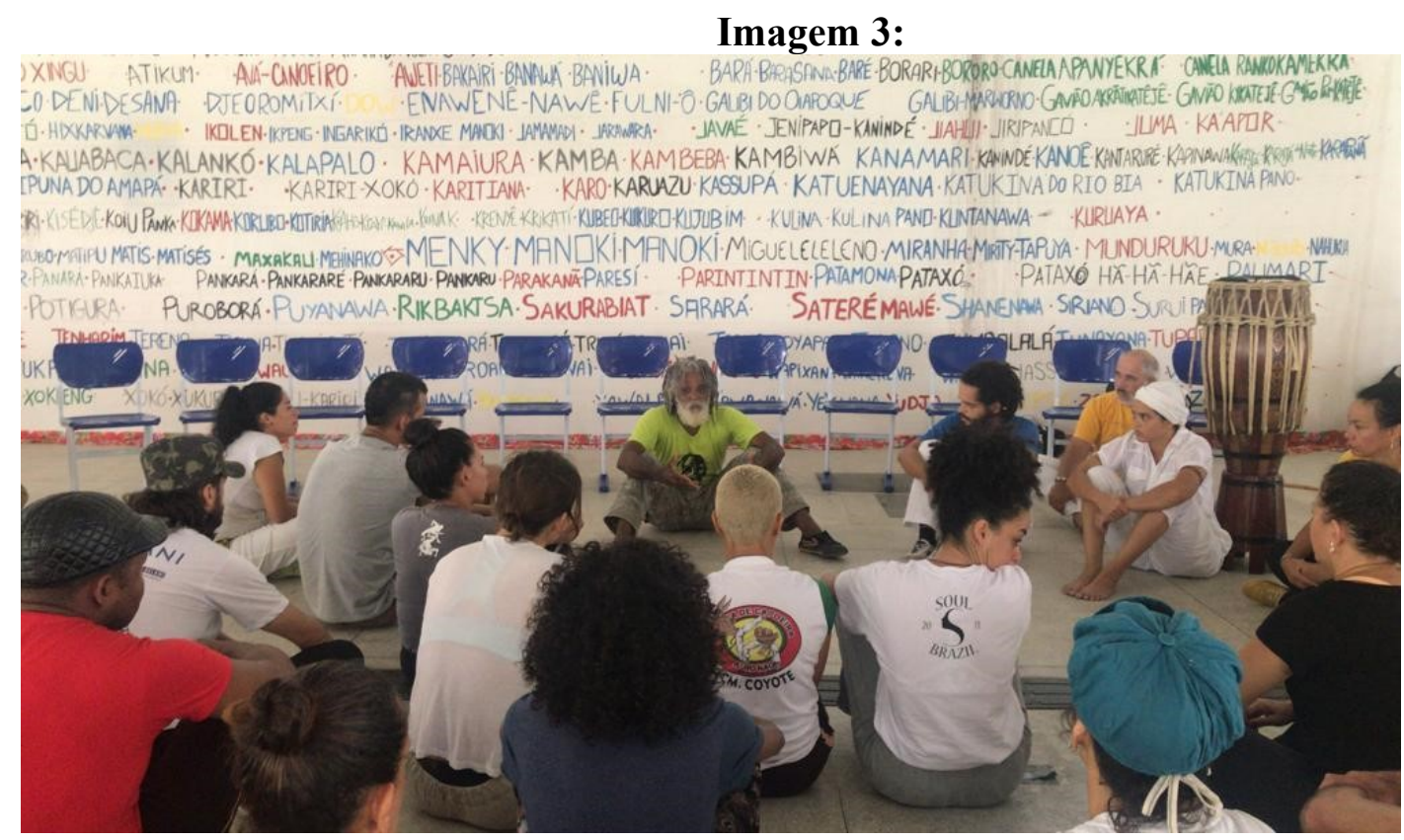

Fonte: Yuri Miguel Macedo (2019)

\section{GBÓ, $A L A F I A^{9}$}

Segundo Gomes (2017), no Brasil, a escola, principalmente a pública, é resultado de uma luta popular pelo direito à educação e entendida como parte do processo de emancipação social. Outrora temos a escola como instituição social que está para regular e normatizar todas as ações do indivíduo, bem como estabelecer elos com a totalidade das relações sociais existentes no contexto social.

A partir do momento que a escola tem a função de estabelecer elos entre os sujeitos e a sociedade, faz-se necessário acercar o debate da instituição educacional enquanto a existência da multiplicidade racial existente no espaço educativo. $\mathrm{O}$ acinte que se vê quando tratado dos estudos das histórias e culturas africanas e afro-brasileiras nestes espaços, se opõe a pedagogia da diversidade (de raça, de gênero, de idade, de culturas) que é apresentada por Gomes (2017), como potencial de derrubar os muros que separam o conhecimento e as experiências sociais.

\footnotetext{
${ }^{9}$ Palavra iorubana que significa ouvir.
} 
A educação básica foi primeiramente destinada aos indígenas, estendendo-se posteriormente aos filhos dos colonos. Já a educação média era destinada aos homens da classe dominante. $\mathrm{O}$ ensino superior era ainda mais restrito, atingido somente pelos filhos dos aristocratas que tinham interesse em fazer parte da classe sacerdotal, e por aqueles que se dirigiam à Europa para estudar e integrar a elite intelectual brasileira, ocupando os cargos de poder do país (Ribeiro, 1993).

A abolição de 1888 colocou os ex-escravizados ${ }^{10}$ nos postos mais baixos da estratificação social, em uma posição que os levou a um desequilíbrio econômico e social, que refletiu no seu despreparo para exercer sua nova posição como homem livre, principalmente como trabalhador livre. Isso quer dizer que a abolição da escravidão sem uma política de inserção social dos negros influenciou fortemente para a concentração da população negra na base da sociedade. Em outras palavras, o ponto de partida para o ingresso no regime de trabalho livre colocou essa população em desvantagens em relação ao homem branco. Os negros conquistaram a liberdade, mas sem igualdade. As desvantagens sociais dos negros foram mantidas mesmo após 1888. (Hasenbalg, 1979, p. $164 / 165)$.

A trajetória do negro no Brasil começa nos primeiros anos após a suposta descoberta do país pelos portugueses. Em meados de 1530, os africanos já eram trazidos para o Brasil, acorrentados como animais, tendo como única função: ser a força de trabalho da aristocracia branca. Em 1535, o comércio de negros escravizados para o Brasil já estava consolidado e crescia rapidamente. As plantações de cana-de-açúcar, atividade econômica importante para a colônia, contavam com uma alta exploração da mão de obra escravizada. (Nascimento, 1978, p. 48).

Contudo, aos poucos os jesuítas acabaram se afastando dessa finalidade, dedicando-se à educação dos filhos da elite, pois assim, conseguiriam maiores lucros e formariam sacerdotes. Nota-se que essa "educação" excluía os que não faziam parte das classes dominantes, sendo que, durante muito tempo o país manteve a educação restrita à pequena parcela da população. (Ribeiro, 1993).

Os conflitos gerados pelo quadro sócio histórico e econômico são fatores que apontam desigualdades sociais e superar essas desigualdades é um desafio que se impõe em todos os âmbitos das práticas sociais, para as quais se deve ter como objetivo a

\footnotetext{
${ }^{10}$ Cf. nota 8 .
} 
promoção do desenvolvimento, de forma a resgatar a capacidade dos sujeitos de projetarem um novo horizonte, como espaço de convivência social que supere as atuais condições sub-humanas de existência e sobrevivência. Não podemos deixar de citar a provocativa frase de Alain (Chartier,1868-1951) "Embalar não é instruir".

Entretanto, não se pode negar que dentre os objetos de luta promovidos pela população negra nos séculos XIX, XX e ao longo do século XXI, a educação constituiuse em um relevante tema, tornando-se importante objeto de luta do Movimento Negro no século XX. Isso porque, os membros do mencionado Movimento admitem que o sistema educacional não é a solução para todos os problemas enfrentados pela população negra, mas consiste em importante instrumento para a formação dos pensamentos que os sujeitos constroem sobre si mesmos e sobre os outros sujeitos, além de viabilizar a constituição dos campos político e intelectual e, ser recorrentemente utilizado pelo mercado de trabalho como requisito para a escolha e exclusão dos indivíduos. (Gomes, 2011, p. 112).

O racismo no Brasil é estrutural e estruturante das relações sociais e, por isso, nem mesmo por parte daqueles que não concordam com o racismo existe qualquer ação capaz de combatê-lo. Isso significa que a sociedade naturalizou toda a violência lançada contra os negros. A sociedade não se assusta com o fato de que a população carcerária brasileira seja composta majoritariamente por negros, nem com o fato de que o número de assassinatos atinge majoritariamente os jovens negros. Isso é tido como natural. (Almeida, 2016).

Dessa forma, pensar o racismo no Brasil não é pensar em atitudes praticadas por pessoas que são expressamente racistas, mas é pensar na própria estrutura social, na própria constituição dos campos e de suas regras de funcionamento. A luta contra o racismo, não é uma luta contra os racistas, mas uma luta pela transformação social. (Almeida, 2016).

A prática docente é sem dúvida o foco central para desconstruir esses ranços provenientes do longo processo histórico que envolve a estigmatização do povo negro a sua cultura. Tradicionalmente a escola reproduz o racismo inclusive presente nos livros didáticos, salvo honrosas exceções. (Vieira, 2019)

Para Macedo e Francischetto (2019), a escola é uma peça fundamental nesta engrenagem que objetiva resgatar a memória. No entanto, não se pode pensar numa escola que, ao contrário, tem servido muito mais para a repetição de uma visão linear 
da história e com inúmeros silenciamentos quanto a memórias outras que não apenas aquelas que fazer parte da versão oficial.

É necessário a discussão do presente, visto que a presente Lei está para o combate do racismo e a desconstrução dos processos racistas institucionalizados. $\mathrm{O}$ racismo e todas as suas implicações, somente irão ser ultrapassados, quando as discussões partirem da ideia da igualdade humana. Gomes (2005) corrobora com a pergunta: Como podemos pensar a escola brasileira, principalmente a pública, descolada das relações raciais que fazem parte da construção histórica, cultural e social desse país? E como podemos pensar as relações raciais fora do conjunto das relações sociais? ${ }^{11}$

\section{REFERÊNCIAS}

ARRUDA, J. B. de. Livro Temático 1; Africanidades e Brasilidades: Saberes, Sabores e Fazeres. João Pessoa: Dinâmica Editora, Ltda - 2007.

ALMEIDA, S.L. O que é racismo estrutural? TV BOITEMPO: Geledés - Instituto da Mulher Negra. 05 out. 2016. Disponível em: <https://www.geledes.org.br/o-que-e-racismo-estruturalsilvio-almeida/> . Acesso em: 01 mar. 2018.

BRASIL, Presidência da República. Constituição da República dos Estados Unidos do Brasil (de 24 de Fevereiro de 1891). Disponível em: $<$ http://www.planalto.gov.br/ccivil_03/constituicao/constituicao91.htm>. Acesso em:

20 mar. 2019.

BRASIL, Presidência da República. Lei no 9.394, de 20 de dezembro de 1996. Disponível em: < http://www.planalto.gov.br/ccivil_03/leis/L9394.htm>. Acesso em: 01 mar. 2018.

BRASIL, Presidência da República. Lei no 10.639, de 9 de janeiro de 2003. Disponível em:< http://www.planalto.gov.br/ccivil_03/leis/2003/L10.639.htm\#art1>. Acesso em: 01 mar. 2018.

CHARTIER, Roger. A ordem dos livros: leitores, autores e bibliotecas na Europa entre os séculos XIV e XVIII. Brasília: Ed. da UnB, 1999.

GOMES, N. L. "Educação e relações raciais: refletindo sobre algumas estratégias de atuação". In: MUNANGA, K. (org.). Superando o racismo na escola. Brasília: Ministério da Educação, Secretaria da Educação Continuada, Alfabetização e Diversidade, 2005; p. 147

GOMES, N.L. O movimento negro educador. 1. ed. Petrópolis: Editora Vozes, 2017. v. 1. 154p

${ }^{11}$ GOMES, N. L. "Educação e relações raciais: refletindo sobre algumas estratégias de atuação". In: MUNANGA, K. (org.). Superando o racismo na escola. Brasília: Ministério da Educação, Secretaria da Educação Continuada, Alfabetização e Diversidade, 2005b; p. 147 
GOMES, Nilma Lino. Diversidade étnico-racial, inclusão e equidade na educação brasileira: desafios, políticas e práticas. Revista Brasileira de Políticas e Administração da Educação. v. 27, n. 1, p. 109-121, jan./abr. 2011. Disponível em:

$<$ http://seer.ufrgs.br/index.php/rbpae/article/view/19971/11602>. Acesso em: 01 mar. 2018.

HASENBALG, Carlos Alfredo. Discriminação e Desigualdades Raciais no Brasil. Rio de Janeiro: Edições Graal, 1979.

MACEDO, Y. M.; FRANCISCHETTO, G. P. P. . Resgate da memória dos perseguidos políticos no Brasil: currículos e saberes emancipatórios. REVISTA IFES CIÊNCIA, v. 5, p. 137-147, 2019. Disponível em: < https://ojs2.ifes.edu.br/index.php/ric/issue/view/1/Yuri\%20Miguel\%20Macedo\%2C\%20Gilsile ne\%20Passon\%20Picoretti\%20Francischetto>. Acesso em: 01 out. 2019.

NASCIMENTO, Abdias do. O genocídio do negro brasileiro: processo de um racismo mascarado. Rio de Janeiro: Editora Paz e Terra S/A, 1978.

PASSOS, Ana Helena Ithamar. Um estudo sobre branquitude no contexto de reconfiguração das relações raciais no Brasil, 2003-2013. 1.ed. Porto Seguro: Editora Oyá, 2019, 180 p.

RIBEIRO, Paulo Rennes Marçal. História da educação escolar no Brasil: notas para uma reflexão. Pandéia. Ribeirão Preto, n. 4, fev./jul., 1993.

VIEIRA, Maurício B. da Silva. EDUCAÇÃO E LEI 10.639/03: QUESTÕES DESAFIADORAS NA ESCOLA. Revista da Associação Brasileira de Pesquisadores/as Negros/as (ABPN), [S.1.], v. 11, n. 28, p. 55-71, jun. 2019. ISSN 2177-2770. Disponível em: $<$ http://abpnrevista.org.br/revista/index.php/revistaabpn1/article/view/717>. Acesso em: 25 jun. 2019.

ZONZON, CN. Capoeira Angola: africana, baiana, internacional. In: MOURA, M. A larga barra da baía: essa província no contexto do mundo [online]. Salvador: EDUFBA, 2011, pp. 130-165. ISBN 978-85-232-1209-4.

Recebido em 30/04/2019

Aprovado em: 30/06/2019 